\title{
CSR, Innovation, and Firm Performance in Sluggish Growth Contexts: A Firm-Level Empirical Analysis
}

\author{
Rachel Bocquet ${ }^{1} \cdot$ Christian Le Bas $^{2} \cdot$ Caroline Mothe $^{1} \cdot$ Nicolas Poussing $^{3}$
}

\begin{abstract}
The few studies that analyze the impact of a combined strategy of innovation and corporate social responsibility (CSR) on firm performance mostly focus on financial performance. In contrast, the current study considers the simultaneous impact of technological innovations (product and process) and CSR on firm growth, which provides a measure of medium-term economic performance. With a sample of 213 firms and a two-step procedure, this study reveals the differentiated effects of strategic versus responsive CSR behavior on the two technological innovation types, as well as the effects of the two innovation types on growth. The findings thus indicate that firms with strategic CSR achieve growth through both their product and their process innovations.
\end{abstract}

Keywords CSR $\cdot$ Economic performance $\cdot$ Growth . Innovation

\section{Introduction}

Corporate social responsibility (CSR) integrates "social and environmental concerns to [firms'] business operations and in their interactions with stakeholders on a voluntary basis" (Commission of the European Communities 2001,

Nicolas Poussing

nicolas.poussing@liser.lu

1 Université de Savoie Mont Blanc, IREGE, 4 Chemin de Bellevue, BP 80439, 74944 Annecy le Vieux Cedex, France

2 ESDES School of Management - Université Catholique de Lyon, 16, rue de l'Abbaye d'Ainay, 69002 Lyon, France

3 LISER , 11, Porte des Sciences, 4366 Esch-sur-Alzette, Luxembourg p. 6) and has, as one of its main benefits, the potential to drive innovation. For example, CSR strategies lead to enhanced technological innovation when integrated into firms' strategies (Bocquet et al. 2013), though empirical research offers contradictory results regarding their effects on financial performance (McWilliams and Siegel 2001). Some studies indicate a positive link (Margolis and Walsh 2003); others find a negative relationship (Gössling 2011). This lack of empirical consensus regarding the relationship between CSR and firm performance reflects a wide array of research issues (McWilliams et al. 2006; Perrini et al. 2011). In particular, an overly strong emphasis on financial instead of economic performance and the use of different methods to measure social and economic performance (Arlow and Gannon 1982; Aupperle et al. 1985; Cochran and Wood 1984; Orlitzky et al. 2003) represent important issues in prior empirical research. Many factors might influence the relationship between CSR and firm performance, such that intangible resources including innovation (Surroca et al. 2010), reputation, and customer satisfaction (Saeidi et al. 2015) could be missing links that can help explain the relationship between CSR and financial performance more accurately.

In response to these research challenges, we analyze the effects of both CSR and technological innovation on firms' economic performance, measured as firm growth. This perspective has the advantage of addressing a mediumterm element of performance. Prior empirical literature already has established a positive effect of innovative implementations on the rhythm of firms' growth and validated Schumpeter's predictions (e.g., the recent survey by Colombelli et al. 2013). But few studies address CSR and innovation together as determinants of firms' growth. By integrating them simultaneously, this study seeks a deeper understanding of the relationship among CSR, innovation, 
and firm growth. We here determine whether innovation influences the relationship between CSR and firm growth. From a foundation in literature that describes the link between CSR and firm performance, we enrich extant analyses by drawing on an evolutionary perspective. With this framework, we also consider how distinct CSR behaviors (strategic versus responsive) and differentiated innovation types (product, process, or both) can affect firm growth, thereby wondering whether the adoption of a CSR strategy necessarily leads to innovation, or whether certain types of CSR strategies are linked to certain types of innovation.

With data gathered from different surveys carried out in Luxemburg, we implement a two-step procedure that addresses several potential problems associated with introducing CSR and innovation concurrently. First, a probit model with instrumental variables enables us to analyze the effects of strategic versus responsive CSR behavior on technological innovation types (process, product, or both). Second, we introduce the predicted innovation variables in an ordinary least square (OLS) model, to measure the effects of innovation types on firm growth. We thus clarify the relationship among CSR, innovation, and firm growth, which has been neither conceptually recognized nor empirically captured by prior research. To the best of our knowledge, this study is the first to examine this relationship by considering both types of CSR behavior (strategic versus responsive) and types of technological innovation (process, product, or both).

The new insights into the relationship among CSR, innovation, and growth are particularly resonant for firms suffering sluggish growth. Whereas prior research often relies on data from periods when macroeconomic growth was consistent and persistent, many European economies continue to experience slow or sluggish growth, which affects not only their economic markets but also their firms' potential growth rate. ${ }^{1}$ The persistent sluggishness (since 2007) shows few signs of changing, making it crucial to consider the focal relationships in a macro-context of demand stagnancy for European firms.

The rest of this article is organized as follows: "Literature Survey and Hypothesis Development" section provides an overview of previous research on the relationship between CSR and firm performance, as well as the potential influence of innovation in this relationship. "Data and Methods" section is devoted to the presentation of our data and empirical models. The data analyses and results follow in "Results" section. In "Discussion and Conclusion"

\footnotetext{
${ }^{1}$ García-Quevedo et al. (2014) show, with a panel of Spanish firms, that deteriorated demand conditions have strong negative effects on R\&D investments.
}

section, we discuss the implications of our findings, some limitations, and avenues for further research.

\section{Literature Survey and Hypothesis Development}

\section{CSR and Firm Performance: Is Innovation the Missing Link?}

Growing literature deals with the economic consequences of corporate social responsibility (CSR) and its effects on financial performance. The results are sometimes contradictory (Chassagnon 2014), yet most studies reveal a positive link (e.g., Margolis and Walsh 2003; cf. Gössling 2011), though to widely varying extents across studies (McWilliams and Siegel 2000; McWilliams et al. 2006; Orlitzky et al. 2003). A key difficulty is that, unlike the measure of corporate social performance, ${ }^{2}$ no immediate measure exists for CSR. This difficulty becomes especially acute when the goal is to assess the impact of CSR on financial performance. Empirical research uses different accounting- or market-based measures (Guiral 2012). As Tang et al. (2012) note, most studies also focus on defining exogenous factors that might affect the relationship of CSR with firm performance, such as the contexts in which a positive link becomes more robust. For example, McWilliams and Siegel (2001) posit that the lack of consensus across empirical studies reflects model specification problems, such as omitting R\&D spending. They also hypothesize that R\&D investments and CSR are highly correlated, because they both are associated with product and process innovation. Their results confirm this correlation; when R\&D intensity appears in an equation, CSR has a neutral effect on profitability. Nor can we ignore co-evolution and loops between CSR and performance (Preston and O'Bannon 1997). Gössling (2011) cites R\&D and risk as important factors that influence the relationship between corporate social performance and financial performance.

A firm's innovation may play a role too (Hull and Rothenberg 2008; Surroca et al. 2010), such that if innovation is one of the independent variables, the CSR-financial performance relationship is no longer significant. Hull and Rothenberg (2008) explicitly address the potential moderating role of innovation in the CSR-financial performance relationship; they find that CSR most strongly affects the performance of low innovation firms. Surroca et al. (2010) demonstrate that intangible resources, including innovation, represent a missing link that can

\footnotetext{
${ }^{2}$ Corporate social performance is more directly applicable (see Gössling 2011), and different measures of it have been suggested, including investment in pollution control equipment, treatment of women and minorities, or relations with customers (Waddock and Graves 1997).
} 
explain the relationships of CSR with financial performance. Although they find no direct relationship between CSR and financial performance, the indirect relationship relies on the mediating effect of a firm's intangible resources (innovation, human capital, reputation, and culture).

Beyond this mainstream view, some nascent literature seeks to describe how a firm might adopt different CSR engagement strategies to determine its financial performance. These strategies entail exogenous factors but also endogenous ones. For example, CSR engagement strategies based on certain organizational capabilities (e.g., absorptive capabilities, complementary resources) seemingly can maximize financial returns on CSR engagement (see Tang et al. 2012).

In turn, three main models have emerged to describe the relation between CSR and economic performance (Gössling 2011). Model 1, the "charitable firm model," asserts that CSR induces no gains. Rather, CSR behavior is only costly, and firms do not expect any direct return. In Model 2, the "legitimacy/commitment model" (Gössling 2011), firms implementing CSR are more profitable (all else being equal) due to external factors, such as their better reputation (Lourenço et al. 2012), gains in legitimacy, and more market flexibility ("license to operate"), as well as internal factors such as human resources. In Model 3, the "strategic CSR model" (Porter and Kramer 2006), CSR produces more business opportunities and innovations, enabling the firm to build competitive advantages (and more growth), through social progress. Such firms redesign products, markets, and productivity in the value chain. The model is anchored in a CSR-driven innovation or strategic CSR innovation approach.

Regarding the links between CSR and economic performance, Lankoski (2009) also suggests that different corporate responsibility issues exert distinct economic impacts. Systematic patterns in these differences depend on whether the challenge is to reduce a negative externality or generate a positive externality, as well as whether the outcome benefits market or non-market stakeholders.

\section{Relationship Among CSR, Innovation, and Firm Growth}

Generally speaking, prior literature considers two types of firm performance indexes: financial or real. The former tend to rely on profitability indexes, such as the rates of return on assets or on equity. For example, a firm should choose an investment that maximizes the equity value criterion, because then it can accrue cash flows and distribute them to stockholders. Creating stockholder value is an increasingly adopted standard for business performance.
However, these financial indexes raise technical difficulties (Oster 1999), even as they exhibit strong correlations with CSR performance (Margolis and Walsh 2003). That is, financial indexes indicate if the firm has allocated its tangible and intangible investments efficiently. In contrast, real performance indexes reveal if the firms have reached certain advantages over their competitors on a product market. As emphasized by evolutionary theory, firms' investment in knowledge capital is critical to their survival (Nelson and Winter 1982; Penrose 1959). For example, technological and non-technological innovations represent primary means to support firm performance, through productivity growth, as confirmed by multiple empirical studies in the tradition opened by Mansfield (1962) and Griliches (1995)—which uses the Firm Technological Performance measure (FTP) as an indicator of firm performance. Sales growth is enhanced by the firm's ability to learn (e.g., Dess and Robinson 1984; Tippins and Sohi 2003). It provides substantial advantages in implementation, because we do not need series of tangible capital to build the measure. Therefore, we focus on growth as a measure of firm (medium- to long-term) performance.

Furthermore, three main theoretical frameworks are available for studying the potential effect of innovation on firms' growth (Colombelli et al. 2013). The first stems from the well-known Gibrat's "law of proportionate effects" (1931), which indicates that firm size distributions are highly skewed, presumably following a log-normal function, so firm size follows a random walk. No deterministic factors explain differences in the extent of a firm's growth. A vast literature deals with the theoretical coherence and empirical relevance of this law (e.g., Cefis et al. 2007), which also gained more attention following an application that showed that the rates of growth of large and/or old firms are often erratic and thus unpredictable (Geroski 1999). For such firms, there should be no deterministic impact of innovation activity on the scale of their growth. However, Gibrat's law is at odds with recent empirical studies that reveal the existence and persistence of heterogeneity in firms' performance (Colombelli and von Tunzelmann 2010).

A second firm growth model, proposed by Jovanovic (1982), predicts disproportionate growth across firms on the basis of age, according to the inverse relationship between firm age and growth. This model reflects a neoclassical concept of firm-specific managerial efficiency (which can be interpreted in terms of human capital): Young firms do not know their efficiency level and learn through production experience. Some firms disappear, while others grow at a rate that decreases with age (for a given size) and with size (for a given age). Thus, younger firms grow faster than older firms (Jovanovic 1982; see also Evans 1987). 
The third theoretical analysis of firm growth represents an evolutionary approach (Nelson and Winter 1982). Firms competing in the same market face uneven production costs, due to differences in their technological capabilities. The differential growth rate across firms in the same sector therefore is a consequence of heterogeneity in their levels of efficiency (or capabilities). Cefis and Marsili (2005), examining the effects of innovation on survival using data about Dutch manufacturing firms, show that firms benefit from an innovation premium that extends their life in the industry, independent of firm age or size. Process innovation in particular seems to have a distinctive effect on survival. Coad and Rao (2008) find, with a large sample of high-tech firms, that growth may or may not relate to innovation activity (i.e., patenting), but innovation is more crucial for "rapid growth" firms. In the same vein, Cassia et al. (2009) provide evidence that universities' knowledge input and output are important determinants of UK entrepreneurial firms' growth. According to Ernst (2001), patent applications increase sales after a lag of 2 or 3 years, depending on the type of the patent system (national or European). That is, the effects of innovation on firm growth are not immediate but occur soon after an invention has been realized. Corsino and Gabriele (2011) use new, unique data pertaining to semiconductor devices commercialized during 1998-2004 around the world; at the corporate level, the most recent innovations significantly affect growth. At the business unit level, the influence of product innovations on business unit growth is even greater than that recorded at the corporate level. Demirel and Mazzucato (2010) study pharmaceutical firms between 1950 and 2008 and observe that the positive impact of R\&D on firm growth is conditional on a combination of firm-specific characteristics, such as firm size, patenting, and persistence in patenting. Colombelli et al. (2013) instead merge three waves of the French Community Innovation Survey (CIS 1992-2004) and find that innovative firms (regardless of innovation type) grow more than non-innovative ones.

Among these frameworks, an evolutionary approach appears particularly well suited to study the complex relationship of CSR, innovation, and growth at the firm level. To the best of our knowledge, no previous study has dealt empirically with these relationships. Therefore, we draw on the evolutionary frame and consider five central phenomena (Dosi 1988): (a) technological opportunities; (b) incentives to exploit those opportunities; (c) firm capabilities to achieve technological changes (including R\&D capacity and a well-trained workforce); (d) organizational arrangements and mechanisms, which facilitate the search for and implementation of technological advances; and (e) appropriability conditions, to generate rents stemming from innovation. In line with a strategic CSR innovation approach (Model 3), we predict that CSR also has an indirect, positive impact on firm economic performance, through innovation.

\section{Hypotheses on the Link Between CSR, Innovation, and Growth}

Our main hypothesis is related to the fact that innovation is the missing link in studies analyzing the effect of CSR on firm performance (here approached through growth, see "CSR and Firm Performance: Is Innovation the Missing Link?" section. above). Moreover, in line with Burke and Logsdon (1996), Porter and Kramer (2006), and Lankoski (2009), we also suggest that different types of CSR (i.e., strategic versus responsive) exert distinct economic impacts. We thus assert that the type of CSR has to be considered when analyzing its effect on innovation.

First, we position ourselves in the strategic CSR framework (Bocquet et al. 2013; Burke and Logsdon 1996; McWilliams and Siegel 2000; Porter and Kramer 2006) which establishes a strong link between the strategic CSR profile and innovation in terms of products and processes. We therefore distinguish the effects of two CSR profiles (strategic versus responsive) on innovation, in line with Burke and Logsdon (1996) who explicitly introduce the strategic dimension of CSR as a means to understand the extent to which CSR leads to value creation. We thus posit:

H1 Strategic CSR has a positive effect on technological innovation.

Second, we have seen that the abundant literature on the impact of CSR on firm performance (Perrini et al. 2011) has provided controversial results. One of the reasons may lie in the fact that if innovation is omitted, the CSR-performance relationship cannot be significant. Taking into account firm's innovation (Hull and Rothenberg 2008; Surroca et al. 2010) may thus of critical importance when studying the link between CSR and performance (through growth). Numerous empirical studies have tested the impact of innovation on firm growth (for an exhaustive review of these studies, see Colombelli et al. 2013), mostly showing the positive and significant relationship. Considering, first, that innovation represents a missing link between CSR and growth, second, that innovation has a positive effect on growth, third, that CSR has to be of strategic in order to be related to innovation, we assume that:

H2 Strategic CSR has a positive effect on firms' growth through the mediating effect of technological innovation. 


\section{Data and Methods}

\section{Data}

For our empirical analysis, we used data from three sources: two surveys conducted by the Luxembourg Institute of Socio-Economic Science (LISER): the Community Innovation Survey [CIS] and Corporate Social Responsibility Survey [CSR] and an administrative dataset (Structural Business Statistics, from the national institute for statistics and economic studies of the Grand Duchy of Luxembourg [STATEC]).

In Luxembourg, the 2008 CIS data were collected by LISER on behalf of STATEC, with the support of the European Commission (Eurostat), using face-to-face interviews among firms that had at least 10 employees (classified as 10-49 employees, 50-249 employees, or 250 employees or more). This mandatory survey achieved a response rate of $86.4 \%$. The final sample includes 615 firms. The second dataset reflected the results of a CSR survey carried out in Luxembourg in 2008 by LISER (for the scale items, see the Appendix). Similar to CIS 2008, firms with more than 10 employees, from all economic sectors, were included in this survey. Among the population of 3296 companies in the national business register provided by STATEC, we built a sample of 2511 firms with more than 50 employees, and we created a stratified random sampling procedure for firms with 10-49 employees. The data collection took place between midSeptember and mid-December 2008, using a mailed questionnaire available in French or German (and English on request). We received 1144 valid responses (response rate: $45.5 \%$ ). The CSR survey collected 2008 data about firms' general characteristics and their integration of CSR into their corporate strategy, namely, whether the firm had adopted CSR in the period under observation (2006-2008) or planned to adopt CSR activities in the subsequent 2 years. $^{3}$

We merged the data from these two surveys. For the merged sample of 266 firms, we gathered data on firm turnover from STATEC, as a structural business statistic and in accordance with European Commission regulations. We deleted records if these turnover data were missing for 2007, 2008, or 2009 or if firms indicated they had no employees (94 firms removed). To assess firm growth accurately, we needed to exclude firms that had experimented with mergers and acquisitions, because these external growth measures could radically increase

\footnotetext{
3 The harmonized survey questionnaire is available at http://ec. europa.eu/eurostat/documents/203647/203701/CIS_Survey_form_ 2008.pdf/e06a4c11-7535-4003-8e00-143228e1b308 (Last access June 2015).
}

turnover, in the case of mergers, or decrease it if a firm were acquired by another firm. Because these effects (positive or negative) generally are substantial in volume, we assumed that an increase (decrease) in the number of employees that exceeded $20 \%$ in 3 years was due to a merger (acquisition). ${ }^{4}$ Because these firms represent outliers with regard to their growth, we removed them from the sample (44 observations removed). Mairesse and Robin (2012) call such removals of extreme values appropriate. Thus, we obtained a final sample of 213 enterprises. To ensure representative results, the data were weighted on the basis of the number of firms per sector and employee size classes.

In our sample, $42 \%$ of firms employed 50-249 people, $39 \%$ between $10-49$, and $19 \%$ more than 250 people. We distinguished manufacturing (mining and quarrying, manufacturing, electricity, and gas and water supply) from service (wholesale trade, transport, storage and communication, financial intermediation, computer and related activities, architectural and engineering activities, and technical testing and analysis) industries, which represented 56 and $44 \%$ of firms, respectively. In terms of CSR behavior and innovation, only $27 \%$ of firms had adopted CSR, and $14 \%$ expected to implement CSR practices in the near future. More firms $(52 \%)$ had introduced one type (single innovators) of technological innovation (process or product), but less than $25 \%$ had introduced both process and product innovations (complex innovators). Firms that had introduced new or significantly improved methods of manufacturing or producing goods or services (process innovation) represented $46 \%$ of our sample, whereas firms that introduced new or significantly improved goods (product innovation) represented $45 \%$. The proportion of firms engaging in innovative activity was greater among firms that had adopted CSR $(28 / 57=49 \%)$ than among others $(57 / 156=36.5 \%)$. Table 1 provides the descriptive statistics related to CSR and innovation behavior.

\section{Variables}

Table 2 contains the definitions of all the study variables and descriptive statistics.

\footnotetext{
4 The $20 \%$ threshold reflects the quantile distribution of firms according to their number of employees. This characteristic concerns in particular the very specific population of high-growth firms. According to the OECD (2007), high-growth firms are those with at least 10 employees that achieve average annualized growth greater than $20 \%$ over a 3-year period, measured by employment levels or employee turnover. In line with Schreyer (2000), small firms are particularly focused on their higher job creation and job destruction rates. In our dataset, 43 of the 44 removed firms employed 10-249 people. These high-growth firms need to be removed, because their growth predominantly comes from external sources, such as mergers and acquisitions (Picard 2006).
} 
Table 1 Firm CSR and innovation behavior

\begin{tabular}{|c|c|c|c|c|c|}
\hline & $\begin{array}{l}\text { Don't } \\
\text { innovate (1) }\end{array}$ & $\begin{array}{l}\text { Innovate in product } \\
\text { or process }(2)\end{array}$ & $\begin{array}{l}\text { Innovate } \\
\text { in process }\end{array}$ & $\begin{array}{l}\text { Innovate } \\
\text { in product }\end{array}$ & Total $(1+2)$ \\
\hline Adopt CSR & 29 & 28 & 5 & 22 & 57 \\
\hline Don't adopt CSR & 99 & 57 & 39 & 46 & 156 \\
\hline Total & 128 & 85 & 44 & 68 & 213 \\
\hline
\end{tabular}

Table 2 Variables and descriptive statistics $(n=213)$

\begin{tabular}{|c|c|c|c|c|}
\hline $\begin{array}{l}\text { Variable } \\
\text { (acronym) }\end{array}$ & Definition & Mean (Std. Deviation) & Min & Max \\
\hline MOYDVCA79 & $\begin{array}{l}\text { Average growth between } 2007 \text { and } 2009 \text { using the arithmetic mean of the two- } \\
\text { period rate of growth in real price (continuous variable) }\end{array}$ & $-0.0005226(0.23379)$ & -0.4202 & 2.7751 \\
\hline DVCA79 & $\begin{array}{l}\text { Growth between } 2007 \text { and } 2009 \text { using the variation of firm turnover in real price } \\
\text { (continuous variable) }\end{array}$ & $-0.02216(0.43011)$ & -0.6789 & 5.1170 \\
\hline INPCS & $\begin{array}{l}\text { Process innovation: the firm introduces new or significantly improved methods } \\
\text { of manufacturing or producing goods or services (dummy variable) }\end{array}$ & $0.46543(0.46543)$ & 0 & 1 \\
\hline INPDT & $\begin{array}{l}\text { Product innovation: the firm introduces new or significantly improved goods } \\
\text { (dummy variable) }\end{array}$ & $0.45539(0.49918)$ & 0 & 1 \\
\hline INNO & Process innovation or product innovation (dummy variable) & $0.52112(0.50073)$ & 0 & 1 \\
\hline COMPLEX & Process innovation and product innovation & $0.24882(0.43335)$ & 0 & 1 \\
\hline CSR & Firms with CSR practices (dummy variable) & $0.26760(0.44375)$ & 0 & 1 \\
\hline STRATEGIC & Firms with strategic CSR profiles (dummy variable) & $0.10798(0.31109)$ & 0 & 1 \\
\hline RESPONSIVE & Firms with responsive CSR profiles (dummy variable) & $0.15962(0.36712)$ & 0 & 1 \\
\hline PLAN_CSR & Firms plan to adopt CSR (dummy variable) & $0.14084(0.34868)$ & 0 & 1 \\
\hline NO_CSR & Firms don't adopt and don't plan to adopt CSR (dummy variable) & $0.59154(0.49271)$ & 0 & 1 \\
\hline RDIN & The firm undertakes internal $R \& D$ activity & $0.26760(0.44375)$ & 0 & 1 \\
\hline EMPHI & $\begin{array}{l}\text { Percentage of employees with higher education (incl. post-secondary college and } \\
\text { university) (dummy variable) }\end{array}$ & $0.25489(0.30430)$ & 0 & 1 \\
\hline MARCONC & The competition of the market is very intense (dummy variable) & $0.58216(0.49437)$ & 0 & 1 \\
\hline SMALL & Total number of employees is $10-49$ (dummy variable) & $0.38967(0.48882)$ & 0 & 1 \\
\hline MEDIUM & Total number of employees is 50-249 (Dummy variable) & $0.417840(0.49437)$ & 0 & 1 \\
\hline LARGE & Total number of employees is more than 249 (dummy variable) & $0.19248(0.39518)$ & 0 & 1 \\
\hline INORG & $\begin{array}{l}\text { Organizational innovation: the firm introduces a new organizational method into } \\
\text { its business practices (incl. knowledge management), workplace organization, } \\
\text { or external relations (dummy variable) }\end{array}$ & $0.54930(0.49874)$ & 0 & 1 \\
\hline INDUS & Belongs to the manufacturing sector (dummy variable) & $0.44131(0.49771)$ & 0 & 1 \\
\hline WORLD & $\begin{array}{l}\text { Most of the firm's turnover between } 2006 \text { and } 2008 \text { comes from outside the } \\
\text { domestic market (dummy variable) }\end{array}$ & $0.525822(0.50051)$ & 0 & 1 \\
\hline
\end{tabular}

\section{Dependent Variables}

The main dependent variable is firm growth, our proxy for firms' economic performance (Orlitzky et al. 2003; Roberts 1992; Russo and Fouts 1997). We measured growth in turnover between 2007 and 2009 in two ways. First, we computed growth for the overall time period using the variation of firm turnover in real price (DVCA79). Second, we calculated an average growth rate, to account for likely evolution during the overall time period. This variable is simply the arithmetic mean of the two-period growth rate (MOYDVCA79). Luxemburg experienced a recession during the study period, such that the rate of variation in the gross national product was $6.6 \%$ in
2007 but $-0.8 \%$ in 2008; 2009 was marked by a severe recession $(-4.1 \%)$. Over these 3 years, the national product trend was nearly flat. With respect to the firms in our sample, the average turnover growth rate for 2007-2009 reflected the overall national tendency $(-0.02 \%)$. The study period also was characterized by very slow growth (or even recessions) in European economies in general; for the Europe 15, for example, the rate of variation was $-0.2 \%$ during 2007-2011.

To assess the role of innovation in the relationship between CSR and firm growth, we considered a second set of dependent variables related to firm innovation. Four dummy variables measure the different types of technological innovation: INPCS if the firm introduces new or significantly improved methods of 
manufacturing or producing goods or services; INPDT if the firm introduces new or significantly improved goods; INNO if the firm introduces at least one of technological innovation (process or product); and COMPLEX if firm introduces both technological innovations (process and product). By distinguishing between single and complex innovators, we account for the idea that a complex innovator that can achieve product and process innovations jointly has an advantage in terms of its potential for creativity and new ideas, compared with more specialized firms (product or process). Moreover, synergetic relations may exist between improvements to products and improvements to processes (Le Bas and Poussing 2014). The new knowledge generated by searching for product improvements might spill over to research projects that aim to improve processes, or vice versa. As a consequence, we expect a complex innovator to grow faster.

\section{Independent Variables}

According to Mattingly and Berman (2006), classification methods are particularly useful to clarify the CSR constructs that researchers intend the data to measure. Using an exploratory factor analysis, they show that the operationalization of the Kinder Lydenburg Domini Ratings Data (KLD) along a single dimension combining positive and negative social actions fails to produce a valid measure of CSR and could hide countervailing effects of social actions on financial performance. They find four distinct classes of social actions (positive and negative) toward distinct stakeholders (technical and institutional). Here we do not use the KLD data. As a consequence, we cannot construct the same CSR classes as those recommended by Mattingly and Berman (2006). However, following their recommendation and in line with CSR engagement strategy literature (Tang et al. 2012), we include two endogenous variables derived from a classification procedure that reflect firms' CSR profiles (strategic versus responsive). For Burke and Logsdon (1996), strategic CSR leads to value creation but requires firm alignment along five dimensions (centrality, proactivity, voluntarism, visibility, specificity).

To determine which firms adopt strategic or responsive CSR profiles, we applied the method suggested by Bocquet et al. (2013). First, we operationalized CSR practices with nine variables, according to the five dimensions identified by Burke and Logsdon (1996). Second, we conducted a principal component analysis on the CSR variables, which resulted in two distinct clusters. Cluster 1 (strategic CSR) comprises intensive CSR adopters, in terms of the number and intensity of the various types of CSR practices they undertake. Their engagement in CSR is supported by clear economic objectives, defined at the firm level, and also requires various formalized practices that reflect the firm's ability to incorporate a stakeholder's objectives into its business operations. In cluster
2 (responsive CSR), firms instead are poor CSR adopters. They have not attained full CSR adoption, lack an asserted economic objective, do not clearly identify their stakeholders, and have not really succeeded in formalizing their CSR practices. We also introduce two dummy variables to account for firms that plan to adopt CSR or not (PLAN_CSR) and those that do not implement any CSR practices (NO_CSR).

We control for factors that explain innovation, to isolate the pure effect related to CSR behavior. As mentioned previously, we adopt an evolutionary perspective, in the belief that the probability of innovation depends on a mix of firm-specific characteristics and sector configurations (Mairesse and Mohnen 2010; Teece 1986). For example, a strong knowledge base includes R\&D capacity and a well-trained workforce (Cohen and Levinthal 1989). In line with McWilliams and Siegel's $(2000,2001)$ recommendations, and recognizing $\mathrm{R} \& \mathrm{D}$ as an important driver of innovation (Mairesse and Mohnen 2005), we included an instrumental variable to reflect whether the firm undertakes internal R\&D (RDIN). This variable meets two necessary conditions: relevance (i.e., correlated with the endogenous variable) and orthogonality (i.e., uncorrelated with the error term of the second equation). Because R\&D expenditures cannot always capture innovation efforts, especially by smaller firms or in service sectors, we also considered the proportion of employees with a higher education degree (EMPHI), which offers a good proxy of firm-level human capital dedicated to innovation. Another important, if controversial, driver is competitive intensity (Covin et al. 1999; Ozsomer et al. 1997). With the belief that intense competition may push all types of innovation, we included a dummy variable (MARCONC), equal to 1 when competition in the firm's market is very intense and 0 otherwise. This variable came directly from the CIS 2008 . We also used the dummy variable WORLD to reflect a firm's export activity. Exports likely favor technological innovation, due to a "learning by exporting" effect that enhances both innovation and productivity (Cassiman and Golovko 2011). When the share of the firm's turnover due to exports is greater than its share of turnover earned within its home country, WORLD equals 1 , and 0 otherwise. Size matters for innovation too (see Russo and Fouts 1997; Wagner 2010), because large firms have more resources to invest in technological activities and exploit external opportunities (Cohen 1995); they also tend to be better organized to protect their innovations and capture the associated rents (Teece 1986). We accounted for these effects with a size measure (SMALL: 10-49 employees, MEDIUM: 50-249 employees, LARGE: more than 249 employees, according to European classifications). In addition, studies of CSR and innovation often include the sector of activity (e.g., Gallego-Alvarez et al. 2011). We used an INDUS variable to control for the firm's sector of activity (manufacturing vs. services). In the group of regressors, we also included the implementation of organizational innovation, which may 
partially determine technological innovation (Haned et al. 2014; Le Bas et al. 2015; Mothe et al. 2015). Diverse organizational practices were aggregated as one variable, to represent the introduction of (at least) one new or significantly improved organizational practice (INORG).

\section{Methods}

We aim to measure the impact of innovation on the growth of the firm when it adopts CSR behaviors. A common method would place the two focal variables (innovation and CSR) on the right side of a growth rate equation. However, we know that there is a relationship between CSR and innovation (Bocquet et al. 2013), which could create an endogeneity bias between innovation and growth (Mansfield 1962): If innovation improves the firm's market positions, more growth means that more resources should to be invested in innovation activities (see Colombelli et al. 2013). The same caution holds for the relation between CSR and growth. In the same way that there is a virtuous loop of innovation, there is a virtuous loop of CSR. To overcome this potential endogeneity bias across the variables, we assess the impact of CSR on firm growth using a twostage model. In line with Crépon et al. (1998) and Hashi and Stojcic (2013), we introduce the instrumental variables. In a first step, we assess the effects of the decision related to CSR on the propensity to innovate (with control variables), using four probit models for each type of innovation. In a second step, we note the relationship between technological innovation types and firm growth, by introducing the predicted innovation variables as explanatory variables in the model that explains the rate of variation in turnover. The model is an ordinary least square (OLS) specification, because turnover variation is a continuous variable. To obtain proper standard errors (Guan 2003; Stock et al. 2002), we used bootstrapping (Camponovo and Otsu 2011) and performed 3000 replications.

\section{Results}

The four models related to the determinants of innovation (see Table 3) show that firms implementing strategic CSR exhibit a higher probability to innovate in their process (Model 3) and in both process and product (Model 4). In contrast, there is no significant impact on product or process innovation (Model 1) or on pure product innovation (Model 2). These results partially validate $\mathrm{H} 1$. In addition, responsive CSR behavior has a significant negative effect on the probability of introducing all types of innovation, in line with previous results that suggest responsive CSR constitutes a barrier to innovation (Bocquet et al. 2013). When we avoid the type of CSR and consider only whether the firm undertakes CSR, this last variable has no significant effect. Analyzing CSR by the type of CSR chosen by the firm thus adds value to the model.
With respect to the effects of the control variables, the factors linked to the firm's knowledge base (RDIN, EMPHI) are significantly positive, as expected. However, internal R\&D activity has no effect in Models 3 and 4 . The coefficients for competition exhibit the expected signs, except for in the product innovation model (Cabagnols and Le Bas 2001). Small firms have a lower propensity to innovate in process and to be complex innovators. The sector variable is significantly positive. Also as hypothesized, firms implementing organizational innovation exhibit a higher probability of being technological innovators.

In the OLS estimation for the second step (see Table 4) related to the link with growth, the innovation variable is a predicted variable, derived from the first step in the estimated model, so that it accounts for the likely effect of CSR. The four models (5-8) show that technological innovation, whatever its type, always has positive impacts on firm growth ${ }^{5}$ (at $10 \%$ ). This result corroborates H2. Two other aspects deserve attention. The effects of the predicted probabilities to implement process innovation (Model 7) and to implement both process and product innovations (Model 8) on growth are greater than the effects of the predicted probability to implement product innovation (Model 6) and to implement product or process innovations (Model 5). This result is consistent with the growth rate definition and in line with recent literature (e.g., Colombelli et al. 2013). Pianta (2005) reveals that process innovation strategies are associated with price competitiveness, whereas product innovation strategies are linked to technological competitiveness (technological leadership). Therefore, cost-reducing process innovations can increase the level of demand for products in the current period and result in higher growth. The effect of technological competitiveness on growth instead is less immediate. Coad and Guenther (2013) show that the timing of the economic effects of product innovation is complex, and Mairesse and Robin (2009) reveal a similar result derived from French CIS data: Process innovation is the main determinant of labor productivity (and there is no effect of product innovation). When an important share of the firm's turnover comes from exports to global markets (dummy WORLD), the growth rate is significantly lower. This result is coherent with the depression that affected the world economy after the financial crisis of 2008. We posit that firms with important foreign markets were more affected by this worldwide recession.

\section{Discussion and Conclusion}

In this article, we have examined the relationship between CSR and firm performance by explicitly accounting for the often neglected effect of innovation (Luo and Bhattacharya 2006;

\footnotetext{
5 We obtained similar results when we measured growth as the variation of firm turnover in real prices (DVCA79).
} 
Table 3 Probit model: determinants of the probability to innovate

\begin{tabular}{|c|c|c|c|c|}
\hline \multicolumn{5}{|c|}{ First step: correction of endogeneity bias } \\
\hline & $\begin{array}{l}\text { Model } 1 \\
\text { INNO }\end{array}$ & $\begin{array}{l}\text { Model } 2 \\
\text { INPDT }\end{array}$ & $\begin{array}{l}\text { Model } 3 \\
\text { INPCS }\end{array}$ & $\begin{array}{l}\text { Model } 4 \\
\text { COMPLEX }\end{array}$ \\
\hline STRATEGIC & $0.03157(0.15326)$ & $0.12053(0.14924)$ & $0.77318 * * *(0.14086)$ & $0.91070 * * *(0.14431)$ \\
\hline RESPONSIVE & $-0.96686^{* * *}(0.13334)$ & $-0.65336 * * *(0.12962)$ & $-0.86916 * * *(0.14062)$ & $-0.55682 * * *(0.14138)$ \\
\hline PLAN_CSR & $0.13159(0.14089)$ & $0.26811 *(0.14162)$ & $0.07973(0.14502)$ & $0.28895 *(0.15202)$ \\
\hline NO_CSR & Ref. & Ref. & Ref. & Ref. \\
\hline INORG & $1.28339 * * *(0.09114)$ & $1.13301 * * *(0.09145)$ & $1.21264 * * *(0.09652)$ & $1.20766 * * *(0.10700)$ \\
\hline RDIN & $2.46347 * * *(0.24552)$ & $2.25908 * * *(0.19331)$ & $-0.05188(0.11244)$ & $0.09851(0.11308)$ \\
\hline EMPHI & $0.69792 * * *(0.13637)$ & $0.99522 * * *(0.13542)$ & $0.68231 * * *(0.13476)$ & $1.00331 * * *(0.13858)$ \\
\hline MARCONC & $0.07284(0.08594)$ & $0.20641 * *(0.08754)$ & $0.15502 *(0.08352)$ & $0.28405 * * *(0.08909)$ \\
\hline SMALL & $-0.13254(0.10524)$ & $-0.02979(0.10695)$ & $-0.50736 * * *(0.09964)$ & $-0.45480 * * *(0.10461)$ \\
\hline MEDIUM & Ref. & Ref. & Ref. & Ref. \\
\hline LARGE & $-0.13959(0.23260)$ & $-0.20435(0.22462)$ & $-0.19789(0.17974)$ & $-0.23067(0.18373)$ \\
\hline INDUS & $0.32344 * * *(0.10479)$ & $-0.09660(0.11040)$ & $0.66105 * * *(0.10020)$ & $0.33680 * * *(0.11008)$ \\
\hline INTERCEPT & $-1.13699 * * *(0.13621)$ & $-1.43601 * * *(0.14036)$ & $-1.38325 * * *(0.13732)$ & $-1.81413^{* * *}(0.15208)$ \\
\hline Pseudo $\mathrm{R}^{2}$ & 0.3452 & 0.3523 & 0.2320 & 0.2549 \\
\hline Log likelihood & -646.75145 & -630.12602 & -672.47296 & -605.87269 \\
\hline Number of observations & 213 & 213 & 213 & 213 \\
\hline
\end{tabular}

Significant effects are in bold

Standard error in brackets. See Table 2 for the variable definitions

*** Significant at $1 \%$; * Significant at $5 \%$; Significant at $10 \%$

Table 4 Determinants of firm growth (OLS)

Second step: correction of the endogeneity bias

\begin{tabular}{|c|c|c|c|c|}
\hline & $\begin{array}{l}\text { Model } 5 \\
\text { MOYDVCA79 }\end{array}$ & $\begin{array}{l}\text { Model } 6 \\
\text { MOYDVCA79 }\end{array}$ & $\begin{array}{l}\text { Model } 7 \\
\text { MOYDVCA79 }\end{array}$ & $\begin{array}{l}\text { Model } 8 \\
\text { MOYDVCA79 }\end{array}$ \\
\hline INNO_PREDICT & $0.10692 *(0.06078)$ & $0.10492 *(0.06116)$ & $0.15610 *(0.08329)$ & $0.13892 *(0.08149)$ \\
\hline INDUS & $0.02479(0.02766)$ & $0.03650(0.02820)$ & $0.01678(0.02659)$ & $0.03418(0.02840)$ \\
\hline SMALL & $0.02799(0.04025)$ & $0.02570(0.04071)$ & $0.04654(0.04280)$ & $0.03977(0.04234)$ \\
\hline MEDIUM & REF. & REF & REF. & REF. \\
\hline LARGE & $0.05797(0.04930)$ & $0.05438(0.05018)$ & $0.07827 *(0.04761)$ & $0.07034(0.04720)$ \\
\hline WORLD & $-0.13529 * * *(0.03918)$ & $-0.13594 * * *(0.03948)$ & $-0.13477 * * *(\mathbf{0 . 0 3 9 1 1})$ & $-0.13416 * * *(0.03946)$ \\
\hline INTERCEPT & $-0.04226(0.03717)$ & $-0.03671(0.03580)$ & $-0.05231(0.04756)$ & $-0.03949(0.04391)$ \\
\hline Adjusted $\mathrm{R}^{2}$ & 0.1518 & 0.1504 & 0.1519 & 0.1450 \\
\hline Number of observations & 213 & 213 & 213 & 213 \\
\hline
\end{tabular}

Significant effects are in bold

Standard error in brackets. See Table 2 for the variable definitions

*** Significant at $1 \%$; ** Significant at $5 \%$; Significant at $10 \%$

Surroca et al. 2010). Unlike previous studies that focus on financial performance, we consider firm growth as a measure of medium-term economic performance. This approach enables us to address a fundamental trait of firms, namely, their capacity to be durably viable in their competitive environments. Combining strategic management theory of CSR and the evolutionary approach of growth, our findings confirm that innovation has a significant role in determining the relationship between CSR and firm growth. Indeed, innovation influences this relationship but only when firms adopt an asserted strategic CSR behavior. In contrast, firms that adopt responsive CSR behaviors face counterproductive, negative consequences.

We contribute to prior literature by revealing two sides of CSR through innovation. In line with Luo and Bhattacharya 
(2006), our results show that previous research has been somewhat overly enthusiastic about the positive benefits of CSR; it has also a "dark side" that generates negative outcomes. These authors attribute the negative returns to a tradeoff between investments in CSR versus the firm's core competencies, such as innovation, which should receive higher strategic priority than CSR initiatives. They also note that firms that are less innovative in meeting stakeholders' needs may send a negative signal of incorrect or opportunistic strategic choices that degrades their legitimacy and performance. In contrast, highly innovative firms can generate positive market value from CSR, given that their stakeholders' needs have been successfully satisfied. In a more recent contribution, Luo and Bhattacharya (2009) also show that the simultaneous pursuit of CSR, advertising, and R\&D may be financially detrimental, because it increases firm idiosyncratic risk. They caution that pursuing all these strategic goals simultaneously is difficult, if not impossible, because most firms experience resource limits.

We provide further evidence of the "dark side" of CSR but argue it is more a question of the context in which firms pursue their strategic goals than of goal quantity. This dark side of CSR should lead to negative effects on performance, but we find instead that it has direct negative consequences only for innovation, probably due to the insights provided by our twostep model. In particular, the costs of CSR may be lower than its benefits, depending on the type of CSR strategy (responsive versus strategic), which affects a firm's innovation. That innovation in turn generates different economic returns to CSR. Our study reveals not only the role of innovation in the relationship between CSR and firm growth but also the conditions that lead to a potential trade-off between innovation and CSR initiatives. A responsive CSR strategy has negative impacts on the propensity to undertake various types of technological innovations; strategic CSR behavior favors innovative probability (in process and in both process and product). Therefore, firms that have fully integrated CSR into their business strategies perform better in terms of innovation and economic performance. In particular, process and complex innovators that benefit from strategic CSR experience more growth. These results support the conjecture suggested by Porter and Kramer (2006) regarding the potential value creation related to strategic CSR. They explicitly argue that firms linking CSR and innovation create synergetic effects and generate greater innovation and growth. Our findings confirm the need "to consider proactive management as an instrument that enables organizations to maintain dynamic alignment with their general business environment" (Ortiz Avram and Khüne 2008 , p. 3) to innovate and thus generate higher economic returns from CSR. Tang et al. (2012) show that a firm's CSR engagement strategy (pace, consistency, relatedness, and path) affects the effectiveness of CSR implementation. Along similar lines, our findings confirm that the manner in which a firm engages in CSR can significantly affect the benefits generated from its engagement. The fine measures of the two CRS strategies and their differentiated effects indicate that consistent engagement may yield different results.

With respect to the impact on firm growth, our results are weakly significant. They might be subject to a limitation, in the sense that the time period in which we calculated growth was characterized by quasi-stagnation in the country under observation (Luxemburg) and for many of the firms in our sample. To what extent did this phenomenon affect our results? Garcia-Quevedo et al. (2014), performing a growth analysis for UK firms during the same time period, show that the lack of trust in the macro-conditions of demand prevented firms from engaging in innovative activities. The macroeconomic context in the Europe 15 nations strongly altered the conditions associated with tracking firm growth drivers. It also increased the difficulty of finding determinants of firm growth, by blurring the causal links among CSR, innovation, and growth.

This study is subject to several further limitations. First, we only tested the effect of innovation on the CSR-firm performance link. Other intangible resources that might mediate or moderate this relationship should be included together in future empirical studies. Second, we used a strategic measure of CSR to distinguish two firm profiles (responsive versus strategic). This approach had the virtue of reflecting whether the firm had integrated all CSR components (environmental, social, business) into its strategic vision or not. However, an interesting extension could test for the existence of complementarity or substitution effects across CSR components (Cavaco and Crifo 2014). Third, the size of the sample represents a limitation. An in-depth analysis of innovations' complementarity would be more feasible with a larger sample. Fourth, other non-technological innovations, such as marketing, organizational, or business model innovations, might have effects. Fifth, researchers might consider a direct effect of CSR on firm growth, beyond the indirect effect through firm innovative behaviors. Sixth, adding another 3 -year time period would provide a means to test for the effects of CSR and innovation in a more longitudinal way, providing some possible explanations of the causal effects. It also would ensure a lag between the dependent variable and the regressors, which could produce more significant coefficients and effects.

From a managerial perspective, this study confirms the importance of CSR as a strategy that favors innovation and firm growth. Moreover, it specifies that all CSR strategies do not lead to the same benefits; the outcome depends on their implementation. Strategic CSR, because it ensures the dynamic alignment of CSR activities with the firm's general business strategy, is likely to meet stakeholders' medium-term expectations. Managers who are keen to implement CSR initiatives therefore should incorporate this strategic dimension. Otherwise, they could be penalized, in terms of both their innovation and their economic returns. 


\section{Appendix}

Questionnaire items from the Corporate Social Responsibility Survey

Is your company active in the field of Corporate Social Responsibility (CSR)?

$\begin{array}{lll}\square \text { Yes } & \square \text { No, but it is scheduled } & \square \text { No } \\ & \text { within less than 2 years } & \Rightarrow \text { End of } \\ & \Rightarrow \text { End of questionnaire } & \text { questionnaire }\end{array}$

Glossary: corporate social responsibility is the voluntary integration of companies' social and ecological considerations into their business operations and relations with their stakeholders. Being socially responsible means not only fully meeting the legal obligations applicable, but going still further, and investing "even more" in the human capital, the environment and relations with stakeholders (employees, customers, suppliers, non-governmental organisations, local authorities and shareholders).

Where is your CSR policy described? (several replies possible)

In your activity report

In a report dedicated to CSR

On your Web site

Nowhere

Other (give details):

Do you have a document describing the values and priority concerns and/or motivations of your company in social and environmental terms?

$$
\square \text { Yes } \quad \square \text { No }
$$

Have you identified the stakeholders targeted by your CSR policy?

$$
\square \text { Yes } \square \text { No }
$$

Before initiating your CSR policy, did you enter into contact with your stakeholders?

$$
\square \text { Yes } \square \text { No }
$$

What are the three main effects you wish to achieve with your CSR policy?

Attracting new employees
Attracting investors
Attracting new customers
Improving the company's image
Standing out from the competition
Anticipating changes in legislation
Reducing your costs
Satisfying your stakeholders
Reducing your impact on the environment

Increasing the well-being of your employees

Other (give details): 
Before initiating your CSR policy, did you: (several replies possible)

Make a list of the actions already carried out within your company Make a list of the actions that could be envisaged within your company Study the actions carried out by other companies Collect information from specialised bodies Collect information from the public authorities Find out about existing CSR standards and labels Assess the costs of implementing CSR

Have you drawn up a schedule for the CSR actions you wish to carry out?

$$
\square \text { Yes } \quad \square \text { No }
$$

Have you drawn up any communication plans on your CSR commitments?

$\begin{array}{lll}\text { In-house } & \square \text { Yes } & \square \text { No } \\ \text { External } & \square \text { Yes } & \square \text { No }\end{array}$

\section{References}

Arlow, P., \& Gannon, M. (1982). Social responsiveness, corporate structure and economic performance. Academy of Management Review, 7(2), 235-241.

Aupperle, K. E., Carroll, A. B., \& Hatfield, J. D. (1985). An empirical examination of the relationship between corporate social responsibility and profitability. Academy of Management Journal, 28(2), 446-463.

Bocquet, R., Le Bas, C., Mothe, C., \& Poussing, N. (2013). Are firms with different CSR profiles equally innovative? An empirical analysis with survey data. European Management Journal, 31(6), 642-654.

Burke, L., \& Logsdon, M. (1996). How corporate social responsibility pays off. Long Range Planning, 29(4), 495-502.

Cabagnols, A., \& Le Bas, C. (2001). The determinants of the type of innovative behaviour at the firm level. In A. Kleinknecht \& P. Mohnen (Eds.), Innovation and firm performance: Econometric explorations of survey data (pp. 112-149). New York: Palgrave.

Camponovo, L., \& Otsu, T. (2011). Robustness of bootstrap in instrumental variable regression, Cowles Foundation Discussion Paper no. 1796. http://cowles.econ.yale.edu/P/cd/d17b/d1796.pdf.

Cassia, L., Colombelli, A., \& Paleari, S. (2009). Firms' growth: Does the innovation system matter? Structural Change and Economic Dynamics, 20(3), 211-220.

Cassiman, B., \& Golovko, E. (2011). Innovation and internationalization through exports. Journal of International Business Studies, 42(1), 56-75.

Cavaco, S., \& Crifo, P. (2014). CSR and financial performance: Complementarity between environmental, social and business behaviours. Applied Economics, 46(27), 3323-3338.

Cefis, E., Ciccarelli, M., \& Orsenigo, L. (2007). Testing Gibrat's legacy: A Bayesian approach to study the growth of firms. Structural Change and Economic Dynamics, 18(3), 348-369.

Cefis, E., \& Marsili, O. (2005). A matter of life and death: Innovation and firm survival. Industrial and Corporate Change, 14(6), $1167-1192$.

Chassagnon, V. (2014). Towards a social ontology of the firm: Emergence, reconstitution, organisation, institution and power. Journal of Business Ethics, 124(2), 197-208.
Coad, A., \& Guenther, C. (2013). Processes of firm growth and diversification: theory and evidence. SPRU Working Paper Series 2013-11. https://www.sussex.ac.uk/webteam/gateway/file. php?name $=2013-11$-swps-coad.pdf \&site $=25$.

Coad, A., \& Rao, R. (2008). Innovation and firm growth in high-tech sectors: A quantile regression approach. Research Policy, 37(4), 633-648.

Cochran, P. L., \& Wood, R. A. (1984). Corporate social responsibility and financial performance. Academy of Management Journal, 27(1), 42-56.

Cohen, W. (1995). Empirical studies of innovative activity. In P. Stoneman (Ed.), Handbook of the economics of innovation and technological change (pp. 182-264). Oxford: Basil Blackwell Handbooks in Economics.

Cohen, W. M., \& Levinthal, D. A. (1989). Innovation and learning: The two faces of R\&D. Economic Journal, 99(397), 569-596.

Colombelli, A., Haned, N., \& Le Bas, C. (2013). On firm growth and innovation: Some new empirical perspectives using French CIS (1992-2004). Structural Change and Economic Dynamics, 26(C), 14-26.

Colombelli, A., \& von Tunzelmann, N. G. (2010). The persistence of innovation and path dependence. In C. Antonelli (Ed.), The system dynamics of technological change (pp. 105-119). Cheltenham: Edward Elgar.

Commission of the European Communities. (2001). Promoting a European framework for corporate social responsibility. Green paper, COM 366 final, Brussels. http://www.europarl.europa.eu/ meetdocs/committees/deve/20020122/com(2001)366_en.pdf.

Corsino, A., \& Gabriele, R. (2011). Product innovation and firm growth: Evidence from the integrated circuit industry. Industrial and Corporate Change, 20(1), 29-56.

Covin, J. G., Slevin, D. P., \& Heelewy, M. B. (1999). Pioneers and followers: competitive tactics, environment and firm growth. Journal of Business Venturing, 15(2), 175-210.

Crépon, B., Duguet, E., \& Mairesse, J. (1998). Research innovation and productivity: An econometric analysis at the firm level. Economics of Innovation and New Technology, 7(2), 115-158.

Demirel, P., \& Mazzucato, M. (2010). The evolution of firm growth dynamics in the US pharmaceutical industry. Regional Studies, 44(8), 1053-1066. 
Dess, G. G., \& Robinson, R. B. (1984). Measuring organizational performance in the absence of objective measures: The case of the privately-held firm and conglomerate business unit. Strategic Management Journal, 5(3), 265-273.

Dosi, G. (1988). Sources, procedures, and microeconomic effects of innovation. Journal of Economic Literature, 26(3), 1120-1171.

Ernst, H. (2001). Patent applications and subsequent changes of performance: Evidence from time-series cross-section analyses on the firm level. Research Policy, 30(1), 143-157.

Evans, D. S. (1987). Tests of alternative theories of firm growth. Journal of Political Economy, 95(4), 657-674.

Gallego-Alvarez, I., Prado-Lorenzo, J. M., \& Garcia-Sanchez, I. M. (2011). Corporate social responsibility and innovation: A resource-based theory. Management Decision, 49(10), $1709-1727$.

García-Quevedo, J., Pellegrino, G., \& Savona, M. (2014). Reviving demand-pull perspectives: The effect of demand uncertainty and stagnancy on $R \& D$ strategy. SPRU Working Papers (May), University of Sussex. https://www.sussex.ac.uk/webteam/gate way/file.php?name=2014-09-swps-gquevedo-pell-savona.pdf \& site $=25$.

Geroski, P. (1999). The growth of firms in theory and in practice. Centre for Economic Policy Research, Working Paper no. 2092, London. http://accounts.unipg.it/ davide.castellani/teaching/ perugia/edi/geroski_1999.pdf.

Gibrat, R. (1931). Les inégalités économiques. Paris: Librairie du Recueil.

Gössling, T. (2011). Corporate social responsibility and business performance. Theories and evidence about organizational responsibility. London: Edward Elgar.

Griliches, Z. (1995). R\&D and productivity: Econometric results and measurement issues. In P. Stoneman (Ed.), Handbook of economics of innovation and technological change (pp. 52-89). Oxford: Blackwell Publishers.

Guan, W. (2003). From the help desk: Bootstrapped standard errors. Stata Journal, 3(1), 71-80.

Guiral, A. (2012). Corporate social performance, innovation intensity and financial performance: Evidence from lending decisions. Behavioral Research in Accounting, 24(2), 65-85.

Haned, N., Mothe, C., \& Nguyen, U. (2014). Firm persistence in technological innovation: The relevance of organizational innovation. Economics of Innovation and New Technology, 23(5-6), 490-516.

Hashi, I., \& Stojcic, N. (2013). The impact of innovation activities on firm performance using a multi-stage model: Evidence from the community innovation survey 4. Research Policy, 42(2), 353-366.

Hull, C. E., \& Rothenberg, S. (2008). Firm performance: The interactions of corporate social performance with innovation and industry differentiation. Strategic Management Journal, 29(7), 781-789.

Jovanovic, B. (1982). Selection and evolution of industry. Econometrica, 50(3), 649-670.

Lankoski, L. (2009). Differential economic impacts of corporate responsibility issues. Business and Society, 48(2), 206-224.

Le Bas, C., Mothe, C., \& Nguyen, U. (2015). The differentiated impacts of organizational innovation practices on technological innovation persistence. European Journal of Innovation Management, 18(1), 110-127.

Le Bas, C., \& Poussing, N. (2014). Are complex innovators more persistent than single innovators ? An empirical analysis of innovation persistence drivers. International Journal of Innovation Management, 18(1), 1-21.

Lourenço, I. C., Callen, J. L., Branco, M. C., \& Curto, J. D. (2012). The value relevance of reputation for sustainability leadership. Journal of Business Ethics, 104(8), 417-428.
Luo, X., \& Bhattacharya, C. B. (2006). Corporate social responsibility, customer satisfaction, and market value. Journal of Marketing, 70(4), 1-18.

Luo, X., \& Bhattacharya, C. B. (2009). The debate over doing good: Corporate social performance, strategic marketing levers, and firm-idiosyncratic risk. Journal of Marketing, 73(6), 198-213.

Mairesse, J., \& Mohnen, P. (2005). The importance of R\&D for innovation: A reassessment using French survey data. Journal of Technology Transfer, 30(2), 183-197.

Mairesse, J., \& Mohnen, P. (2010). Using innovation surveys for econometric analysis. Working Paper 15857. National Bureau of Economic Research (NBER), Cambridge, MA.

Mairesse, J., \& Robin, S. (2009). Innovation and productivity: A firmlevel analysis for French manufacturing and services using CIS3 and CIS4 data (1998-2000 and 2002-2004). http://congres.afse. fr/docs/2010/ 543572jmsr_ep2009.pdf]. 28.03.2011.

Mairesse, J., \& Robin, S. (2012). The importance of process and product innovation for productivity in French manufacturing and services industries. In M. Andersson (Ed.), Innovation and growth: from $R \& D$ strategies of innovating firms to economywide technological change (pp. 128-152). Oxford: Oxford University Press.

Mansfield, E. (1962). Entry, Gibrat's law, innovation and the growth of firms. American Economic Review, 52(5), 1023-1051.

Margolis, J. D., \& Walsh, J. P. (2003). Misery loves companies: Rethinking social initiatives by business. Administrative Science Quarterly, 48(2), 268-305.

Mattingly, J. E., \& Berman, S. L. (2006). Measurement of corporate social action: Discovering taxonomy in Kinder Lydenberg Domini ratings data. Business and Society, 45(1), 20-46.

McWilliams, A., \& Siegel, D. (2000). Corporate social responsibility and financial performance: Correlation or misspecification? Strategic Management Journal, 21(5), 603-609.

McWilliams, A., \& Siegel, D. (2001). Corporate social responsibility: A theory of the firm perspective. Academy of Management Review, 26(1), 117-127.

McWilliams, A., Siegel, D., \& Wright, P. (2006). Corporate social responsibility: Strategic implications. Journal of Management Studies, 43(1), 1-18.

Mothe, C., Nguyen, P., \& Nguyen, U. (2015). Complementarities in organizational innovation practices: Evidence from French industrial firms. Economics of Innovation and New Technology, 24(6), 569-595.

Nelson, R. R., \& Winter, S. (1982). An evolutionary theory of economic change. Cambridge, MA and London: The Belknap Press.

OECD (2007). Eurostat-OECD manual on business demography statistics. http://www.oecd.org/std/39974460.pdf.

Orlitzky, M., Schmidt, F. L., \& Rynes, S. L. (2003). Corporate social and financial performance: A meta-analysis. Organization Studies, 24(3), 403-441.

Ortiz Avram, D., \& Kühne, S. (2008). Implementing responsible business behavior from a strategic management perspective: Developing a framework for Austrian SMEs. Journal of Business Ethics, 82(2), 463-475.

Oster, S. M. (1999). Modern competitive analysis. New York: Oxford University Press.

Ozsomer, A., Calantone, R., \& Di Benedetto, C. A. (1997). What makes firms more innovative? A look at organizational and environmental factors. Journal of Business and Industrial Marketing, 12(6), 400-416.

Penrose, E. (1959). The theory of the growth of the firm. New York: Wiley.

Perrini, F., Russo, A., Tencati, A., \& Vurro, C. (2011). Deconstructing the relationship between corporate social and financial performance. Journal of Business Ethics, 102(1), 59-76. 
Pianta, M. (2005). Innovation and employment. In J. Fagerberg, D. Mowery, \& R. Nelson (Eds.), The Oxford handbook of innovation (pp. 568-598). Oxford: Oxford University Press.

Picard, C. (2006). Les gazelles en France. INSEE, Direction des Etudes et Synthèses Economiques, Document de travail, G2006/ 02 .

Porter, M. E., \& Kramer, M. R. (2006). The link between competitive advantage and corporate social responsibility. Harvard Business Review, 84(12), 78-92.

Preston, L. E., \& O'Bannon, D. P. (1997). The corporate socialfinancial performance relationship. Business and Society, 36(4), 419-429.

Roberts, R. W. (1992). Determinants of corporate social responsibility disclosure: An application of stakeholder theory. Accounting, Organizations and Society, 17(6), 595-612.

Russo, M. V., \& Fouts, P. A. (1997). A resource-based perspective on corporate environmental performance and profitability. Academy of Management Journal, 40(3), 534-559.

Saeidi, S. P., Sofian, S., Saeidi, P., Saeidi, S. P., \& Saaeidi, S. A. (2015). How does corporate social responsibility contribute to firm financial performance? The mediating role of competitive advantage, reputation, and customer satisfaction. Journal of Business Research, 68(2), 341-350.

Schreyer, P. (2000). High-growth firms and employment. OECD Science, Technology and Industry.,. doi:10.1787/861275538813.
Stock, J. H., Wright, J. H., \& Yogo, M. (2002). A survey of weak instruments and weak identification in generalized method of moments. Journal of Business \& Economic Statistics, 20(4), $518-529$.

Surroca, J., Tribò, J. A., \& Waddock, S. (2010). Corporate responsibility and financial performance: The role of intangible resources. Strategic Management Journal, 31(5), 463-490.

Tang, Z., Hull, C. E., \& Rothenberg, S. (2012). How corporate social responsibility engagement strategy moderates the CSR-financial performance relationship. Journal of Management Studies, 49(7), 1274-1301.

Teece, D. J. (1986). Profiting from technological innovation: Implications for integration, collaboration, licensing and public policy. Research Policy, 22(2), 112-113.

Tippins, M. J., \& Sohi, R. S. (2003). IT competency and firm performance: Is organizational learning a missing link? Strategic Management Journal, 24(8), 745-761.

Waddock, S., \& Graves, S. (1997). The corporate social performancefinancial performance link. Strategic Management Journal, 18(4), 303-319.

Wagner, M. (2010). Corporate social performance and innovation with high social benefits: A quantitative analysis. Journal of Business Ethics, 94(4), 581-594. 